\title{
Critical Evaluation of Possible Contamination by Toxic Metals in Powdered Milk During the Production Process
}

\author{
Fernando B. Mainier ${ }^{\star}$, Dalmo Lima Filho**, Aída Maria Bittencout Filha* \\ *Escola de Engenharia, Universidade Federal Fluminense, Niterói, RJ, Brazil \\ **Instituto de Química, Universidade Federal Fluminense, Niterói, RJ, Brazil \\ *fmainier@uol.com.br
}

\begin{abstract}
This study used an interdisciplinary approach to bring together some of the necessary and fundamental knowledge in the processing of powdered milk, mainly in relation to the materials used in the manufacture of equipment used in industrial processing. In order to clarify this issue, questions are presented on problems of corrosion, erosion and contamination by microorganisms that can generate or contribute to toxic metal leaching and consequently contaminate milk powder. In this work, we developed a method using atomic absorption spectroscopy with electro-thermal atomization to determine levels of cadmium, lead and nickel. To evaluate the possibility of contamination, we tested 15 samples of various brands of milk powder purchased in shops. Fortunately, the levels of these elements, in all samples, were lower than the maxima allowed under Brazilian law. However, this method of chemical analysis can be used as a tool of quality as the contamination that may occur during the production process.
\end{abstract}

\section{Keywords}

Powdered milk; contamination; corrosion; cadmium; lead; nickel.

\section{SUBJECT}

Corrosion and possible contamination in powdered milk production process.

\section{Council for Innovative Research}

\author{
Peer Review Research Publishing System
}

\section{Journal: Journal of Advances in Chemistry}

Vol. 8, No. 2 


\section{INTRODUCTION}

Currently, there is a growing interest for management concerning public health problems caused by food poisoning and other degenerative diseases whose causes can be toxic metals, microorganisms, insecticides and herbicides used plantations, fungal toxins, etc. The presence of hazardous contamination in food is rarely perceived by the consumer, hence the ease with which many people are affected simultaneously without understanding or realizing the intrinsic reasons.

The World Health Organization (WHO) and the scientific community in general have devoted special attention to organic and inorganic chemical contaminants due to their high persistence in the environment, high toxicity and ability to cause adverse effects to human health and other living organisms. Aiming at the promotion of chemical safety, and due to sufficient toxicological evidence, the WHO has emphasized the need for international action on the control and reduction of such substances in different environmental compartments [1].

The Brazilian dairy sector is one of the country's most important agribusinesses. It is estimated that primary production employs more than 3.6 million people. The activity is practiced throughout the country, in more than one million rural properties. Currently, the agro-industrial production system is based on several methods of production, ranging from more archaic to the most modern technologies. Thus, many factors determine the influence of man and agribusiness on the environment. It also becomes essential to assess, by a critical view, the degree of contamination from the use of techniques, technologies, materials or chemicals products used directly or indirectly in the production of processed foods [2].

The issue of food safety has been gaining global importance and audits are growing on the part of government agencies, businesses, consumers and society itself so that food does not negatively affect consumer health. The production of milk powder is one of the routes of direct use of cow's milk; the probable sources of contamination can be in the fresh milk itself or from the production process of powdered milk. To illustrate the relevance of the theme of contamination presented in this study, some cases of the contamination of powdered milk distributed by the media in recent years can be cited.

1) The National Health Investigation Agency of Brazil (ANVISA) banned yesterday the marketing and the use of powdered milk for infants probably contaminated with iron [3];

2) The Food and Drug Administration (FDA) warned the company manufacturer of milk powder to remove the product from the market for not possessing sufficient levels of phosphorus and calcium [4];

3) An American company removed from the market millions of powder milk cans to children after confirming the presence of beetle in lots of the product during the manufacturing process. The FDA indicated that intake of this type of beetle could "cause uneasiness and irritation in the gastrointestinal system, causing loss of appetite of children [5].

The present work does not aim to make sense of the information disseminated by the national and international media, but only to propose a method of chemical analysis for the assessment of toxic metals in powdered milk, demonstrating that the possibility of contamination that may occur during the industrial processing of powdered milk.

\section{THE PRODUCTION MILK POWER}

The main stages in the production of milk powder are presented based on the simplified processing flowchart presented below in Figure 1.

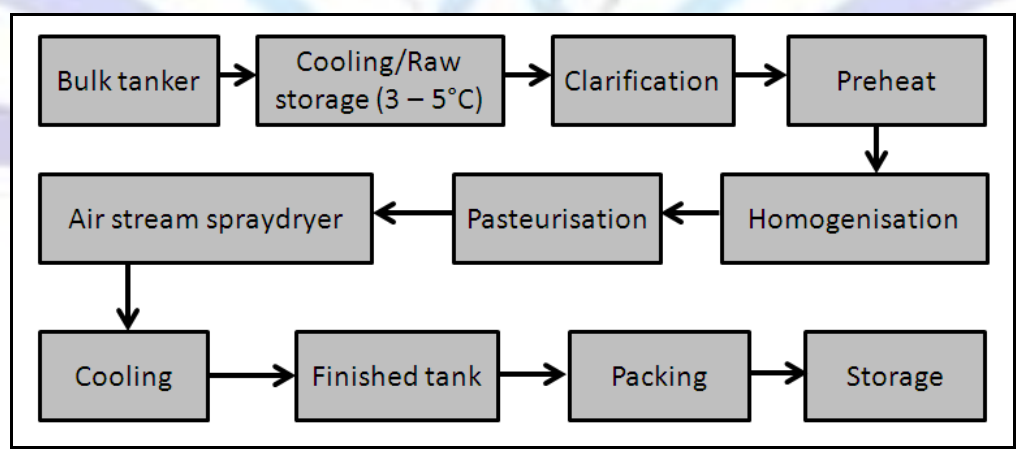

Fig 1: Stages of the production process of milk powder

All the milk received is cooled to a temperature that varies from $3^{\circ} \mathrm{C}$ to $5{ }^{\circ} \mathrm{C}$ in stainless steel, isothermal tanks until it is sent to the manufacturing process. The milk is standardized as to its fat content, ensuring an adequate nutritional composition in the final product. Then, the milk is pre-heated and pasteurized at $75^{\circ} \mathrm{C}$ for 15 seconds, and then stored in tanks at temperatures ranging from $5^{\circ} \mathrm{C}$ to $7^{\circ} \mathrm{C}$. The pasteurization process eliminates microorganisms that can damage the product and cause disease.

The standardized milk at the correct concentration passes through a tubular heater into a set of three vacuum concentrators, where the evaporation of some of the water from the milk occurs. Milk contains, on average, $87 \%$ water and, after this process, the amount of water is reduced to around $57 \%$. By evaporating the water from the milk at a 
temperature of $75{ }^{\circ} \mathrm{C}$, this retains the nutritional value of the final product. The milk is then concentrated to $43 \%$ solids and pumped into a drying tower, where it is sprayed in counter flow into a stream of hot air at $175{ }^{\circ} \mathrm{C}$. The hot air, when it contacts the powdered milk, absorbs any moisture and the milk dust falls in the form of particles to the bottom of the drying chamber. The air is then removed by an exhaust system, which forces the air and dust through a cyclone where, by centrifugal force, air is eliminated and the powdered milk is sent to a system of vibrating screens, for the retention of undesirable particles. Subsequently, the milk powder is stored in a storage tower. The filling of packages is performed automatically, without any manual contact. These packages can be tin or aluminium cans, metalized polyester or multiwall bags.

\section{POSSIBLE SOURCES OF CONTAMINATION BY TOXIC METALS IN POWDERED MILK INDUSTRIALIZATION}

The equipment and materials used in the milk processing industry, generally, are designed and dimensioned for continuous or batch processes. Most of the time, the scheme of work is continuous day and night for many months before the equipment is subjected to a regime of sanitization in order to maintain the fundamental hygiene levels when rendering products of guaranteed quality. The tanks used in the processing of milk industry are generally constructed of AISI 304 and AISI 316 stainless steel, although it is also possible to find other types of low alloy steels with lower corrosion resistance and metallic coatings applied to carbon steel. The main equipment used in the processing of milk includes mixers, heat exchangers, tanks, pasteurizers, autoclaves, pumps, filters, etc. Figure 2 shows some of the equipment used in milk processing.
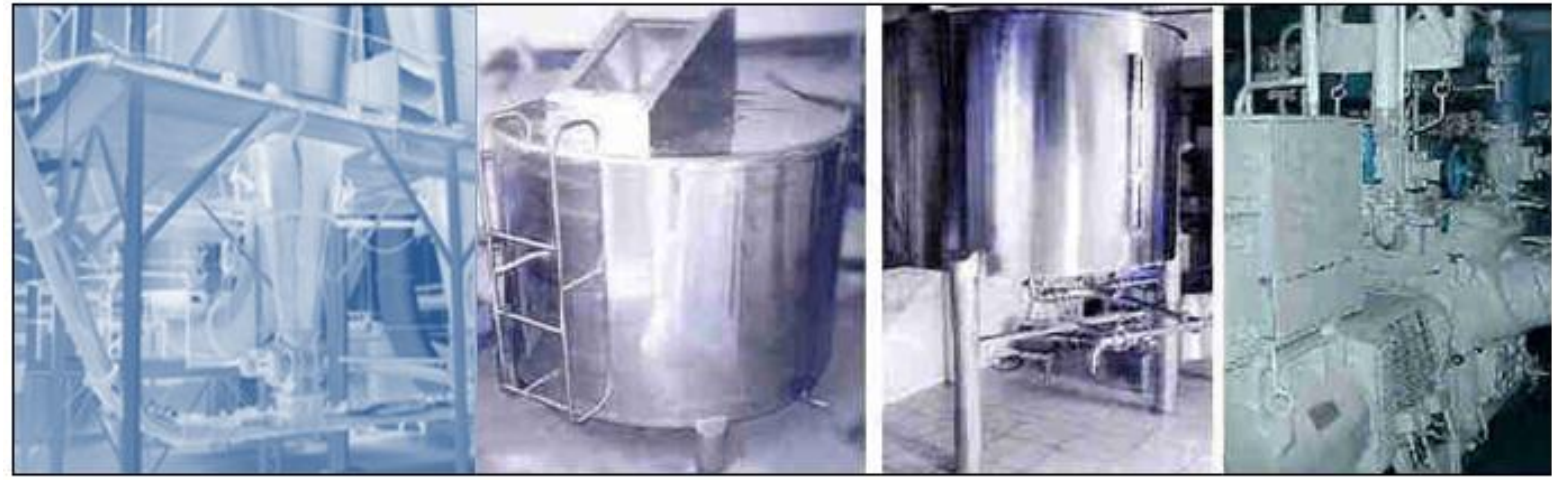

Fig 2: Milk industry equipment's

The cleaning process is critical in milk processing, as it prevents the growth of microorganisms between the producer and consumer of milk, as shown in the mechanism presented in Figure 3. If total removal of microorganisms is not achieved on the inner walls of the pipes or internal equipment, contamination problems are possible with the consequent loss of the final product $[6,7]$.

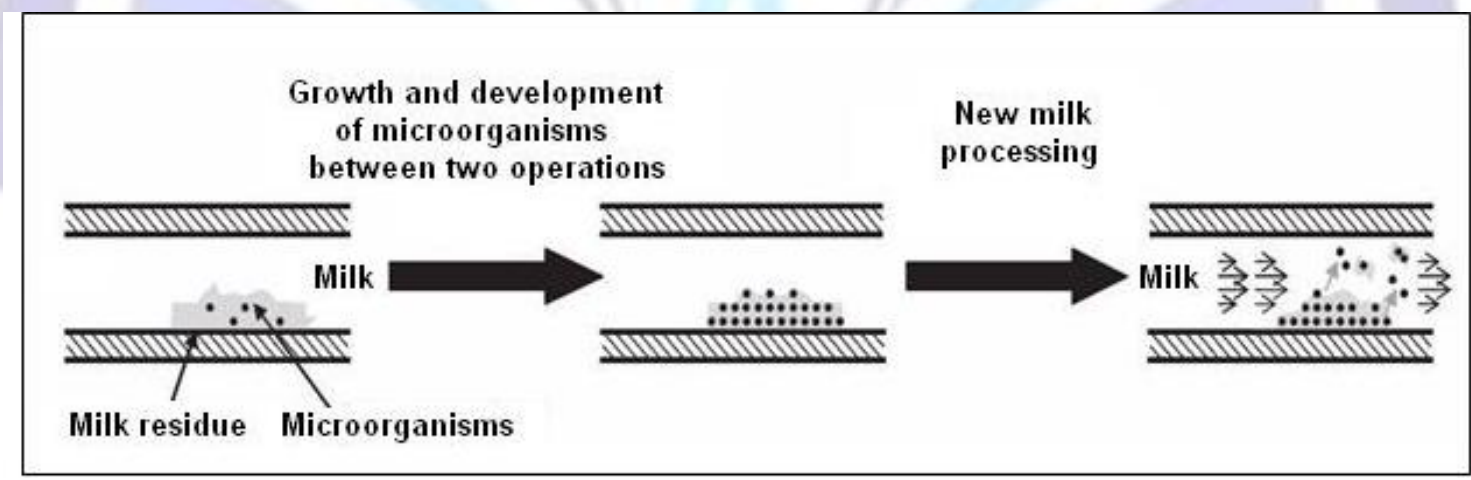

Fig 3: Mechanism of microorganism contamination during milk processing.

\section{Source with modifications [6]}

In the processing of milk, depending on the operating conditions, there is a great possibility of bacterial biofilm formation, resulting in the formation of polymeric deposits, clogging, contamination and consequently the loss of production and a reduction in monetary revenue $[8,9]$.

The formation of incrustations that occur in the heat exchangers in the dairy industry is a complex phenomenon and the mechanisms behind this are not always clear, although there is a relationship between the denaturation of proteins with temperature and incrustations. It is not possible to completely eliminate fouling in heat exchangers, simply due to the fact that denaturation and aggregation reactions begin as soon as the milk is subjected to heating. Most deposits are 
comprised of proteins and calcium phosphate. However, deposits can be inhibited or reduced by selecting suitable thermal conditions, ultrafiltration parameters and flow velocity [10, 11, 12].

Another point that deserves attention is the metal elements used during the construction and assembly of industrial equipment. This can result in cracks, pitting, cavities, corrosion products, rebounds or defects in the welds, as shown in Figure 4.

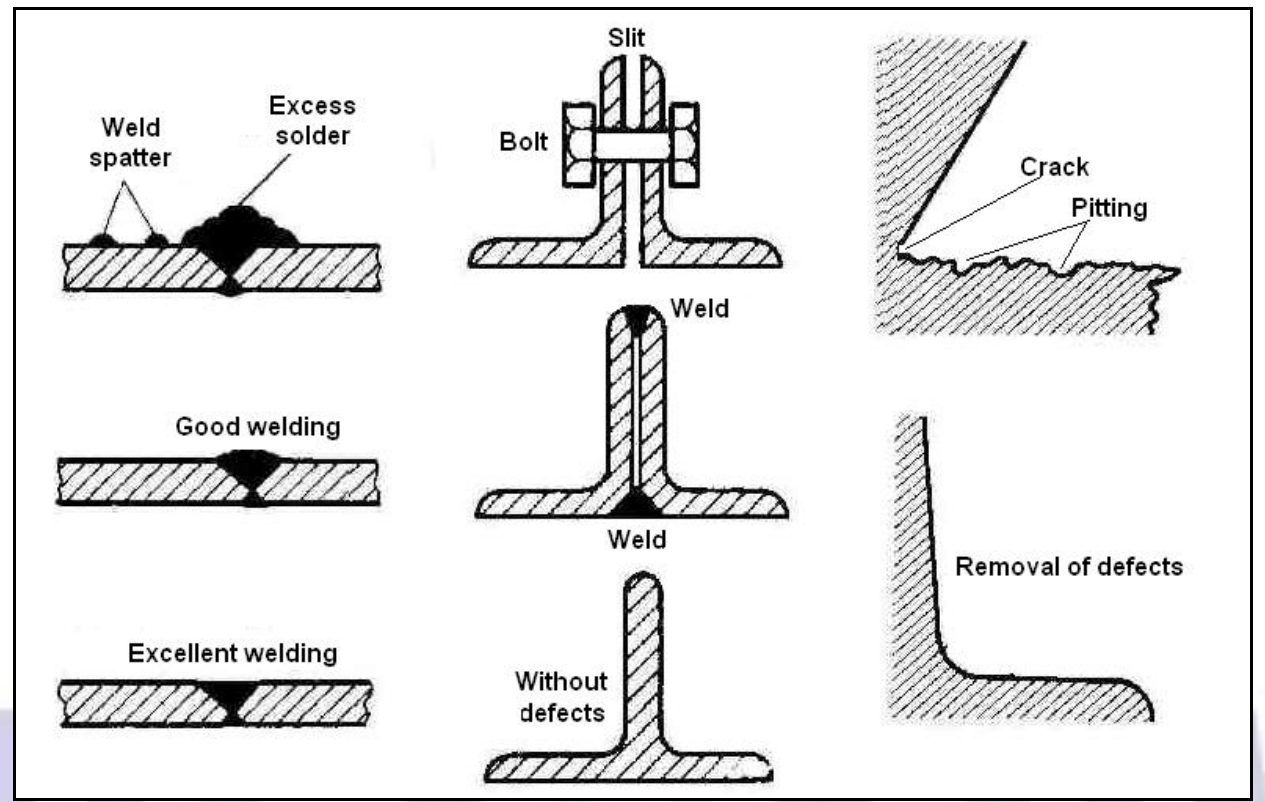

Fig. 4 - Elements existing in the construction and assembly of equipment.

\section{Source with modifications [13]}

Such imperfections or wear provide anchoring locations for inorganic and/or organic deposits that can occur on the inside of pipes and/or equipment. Whether associated with microorganisms or not, these imperfections restrict flow and even cause blockages, as shown in Figure 5.

Cleaning operations with dry or saturated steam with or without detergents and sterilizing substances are used to remove adherent deposits at metal surfaces and thus provide conditions suitable for industrialization of milk-based foods. The literature of milk manufacturing provides reports on corrosion problems considering that the use of stainless steel in the manufacture of industrial equipment practically eliminates the corrosion process. It is essential to note that this statement is not true. Stainless steels are alloys, with low carbon steel containing 12 to $26 \%$ chromium and up to $22 \%$ nickel and other metals to give specific properties. According to ASTM (the American Society for Testing and Materials), there are more than 80 different types with varying chemical compositions. Stainless steels that have a passivation layer of chromium oxide have excellent corrosion resistance in oxidizing media. With increasing chromium and molybdenum contents, the steels become increasingly resistant to aggressive solutions. These steels are inert in relation to freshwater, atmospheres in general, water vapour, and the manufacturing processes of milk-based foods [14].

Stainless steels have different behaviours than carbon steels, because in the presence of oxygen or oxidants, a thin protective coating forms on the surface called a passivation layer. This consists of hydrated chromium oxides of a continuous nature that are adherent, non-porous and insoluble. For passivation to occur, the presence of an oxidizer is essential. Aerated conditions are favourable passivation film formation, while conditions without dissolved oxygen are associated with a reduced possibility of passivation layer formation $[15,16]$. The presence of chlorides $\left(\mathrm{Cl}^{-}\right)$, bromides $\left(\mathrm{Br}^{-}\right)$ and fluorides $\left(\mathrm{F}^{-}\right)$can cause damage to the passivation film with occurrence pitting. Pitting increases with the resulting partial loss of the passivation layer, and at temperatures exceeding $60{ }^{\circ} \mathrm{C}$, stress corrosion cracking may occur, causing serious damage to the equipment $[15,16]$. 


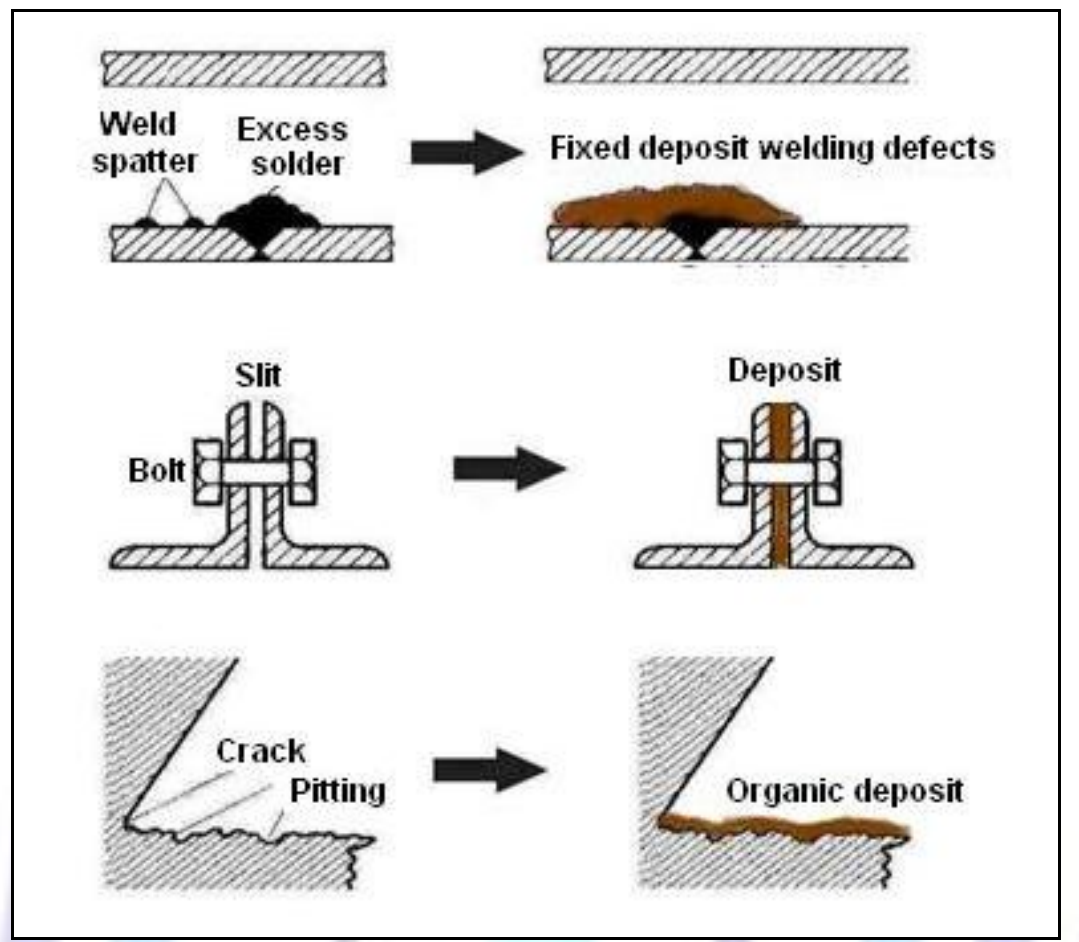

Fig. 5 - Construction elements with fixed deposits on defects. Source with modifications [13]

The corrosion of stainless steels can occur under deposits (in the cases referred to in Figure 5), with the aid of reducing bacteria and in media containing chlorides. Resistance to pitting and crevice corrosion typically increases with increasing contents of chromium, molybdenum and nitrogen. This property is very important if the stainless steel is to be used in a chloride-containing environment.

In addition, the equipment is subject to the mechanical stresses (tensile and compression), which can promote intergranular and transgranular corrosion, as shown by metallography in Figure 6.

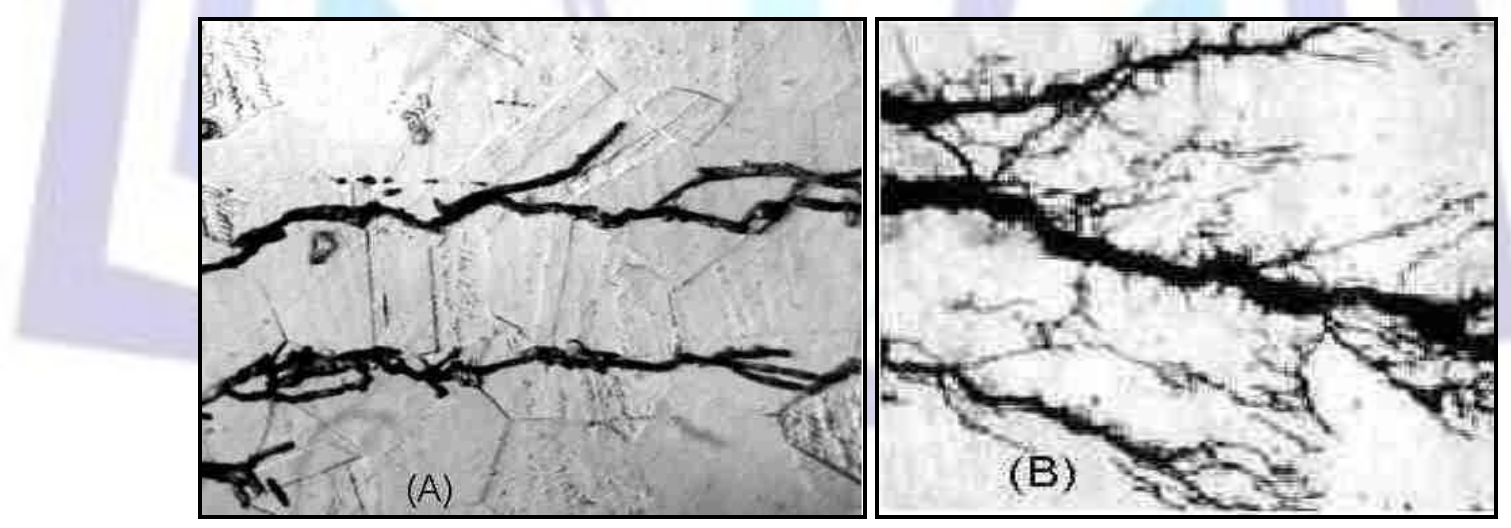

Fig. 6 - Intergranular (A) and transgranular (B) corrosion

Another process that deserves highlighting is the corrosion-erosion case applied to stainless steel passivation layer when the loss by erosion provided by the speed of the pump rotor that ends up providing in pitting intense, as shown in Figure 7 . An example of corrosion-erosion of an AISI 304 stainless steel impeller operated in the sugar industry is shown in Figure 8. 


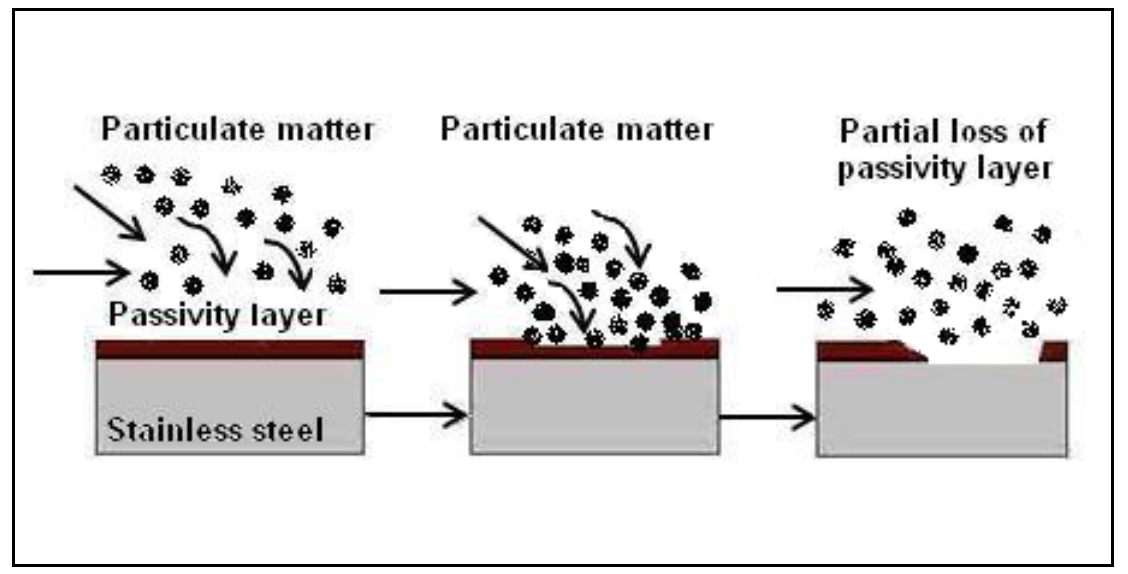

Fig. 7 - Corrosion-erosion mechanism of stainless steel

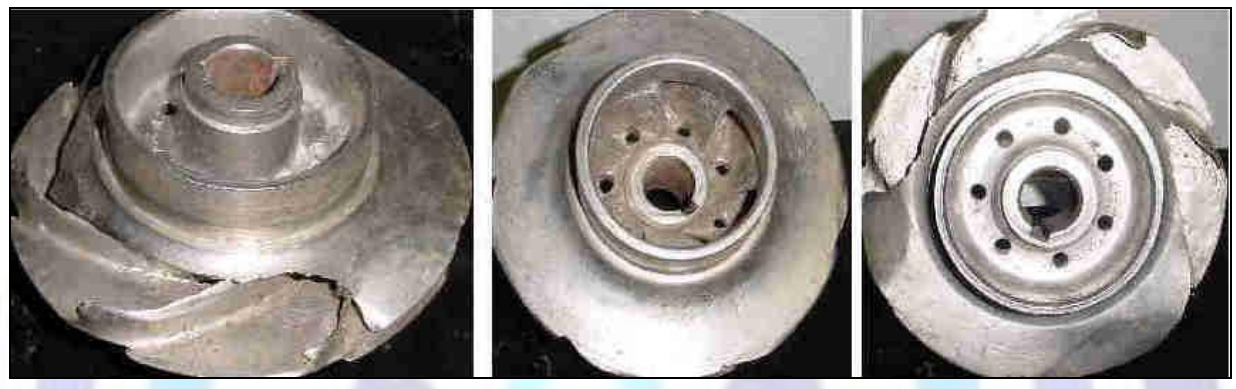

Fig.8 - Corrosion-erosion of a stainless steel rotor

On the basis of these facts, it is possible to assume that pitting of equipment manufactured of stainless steel occurs, associated with possible defects, fouling, cleaning with detergents and oxidizing disinfectant solutions (sodium hypochlorite- $\mathrm{NaClO}$ ) and the possibility of chloride $\left(\mathrm{Cl}^{-}\right)$in the destruction of the passivation layer on stainless steel. Therefore, the corrosion of stainless steel allows contamination with the following ions: $\mathrm{Fe}^{2+}, \mathrm{Fe}^{3+}, \mathrm{Ni}^{2+}$ and $\mathrm{Cr}^{3+}$.

Another point that should be highlighted is the presence of $\mathrm{Cd}^{2+}$ ions from possible wear by erosion-corrosion of bolts and washers made of cadmium-coated steel. Figure 9 shows two corroded bolts compared with a bolt that has not undergone the corrosion process [17].
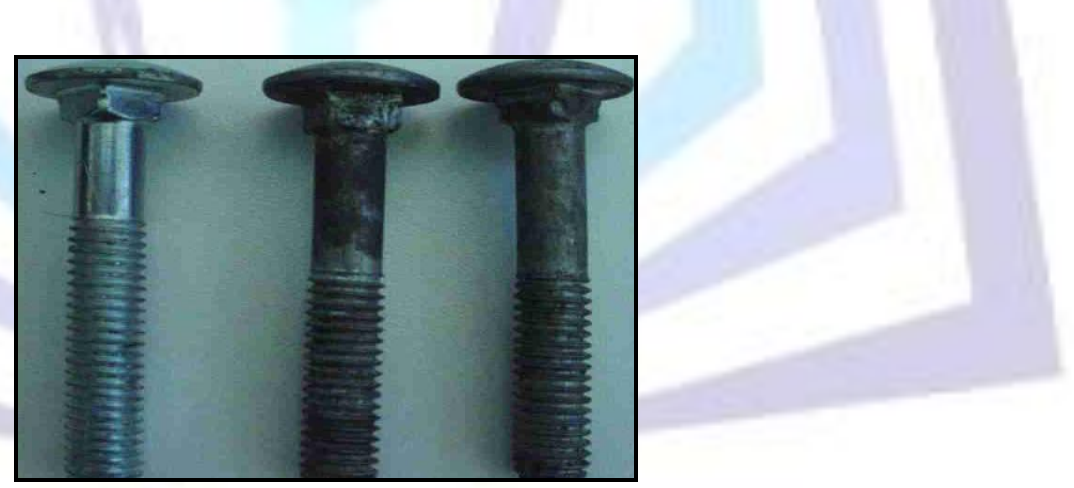

Fig. 9 - Corroded cadmium-coated steel bolts

Based on this evidence, it can be confirmed that the materials and equipment used in the industrial processing of milk are not immune to corrosion and, consequently, contamination by toxic metals can occur in this process.

\section{CHEMICAL ANALYSIS OF POWDERED MILK}

First, it was important to clarify that the present work merely aimed to determine the contamination levels of powdered milk for nickel, lead and cadmium, although there may be contamination with other metallic or non-metallic materials. Moreover, formalized detection and validation levels are regulated by the Brazilian public health agencies.

Table 1 presents the maximum limits of tolerance for the presence of some metals in milk, according to Brazilian law, with an emphasis on the elements under study. In Brazil, the law in force that establish the maximum tolerance for inorganic contaminants and additives in foods is the Portaria $n^{\circ} 685$ (Law $n^{\circ}$ 585, 27/09/1998 of National Health Surveillance Agency - ANVISA) subordinate to Ministério da Saúde (Ministry of Health). 
Table 1- Maximum limits of tolerance for the presence of some metals in milk, according to Brazilian law, with an emphasis on the elements under study.

\begin{tabular}{|l|c|}
\hline \multicolumn{1}{|c|}{ Metal } & $\begin{array}{c}\text { Maximum limits of tolerance } \\
(\mathrm{mg} / \mathrm{L})\end{array}$ \\
\hline Antimony (Sb) & 2.00 \\
\hline Arsenic (As) & 0.1 \\
\hline Cadmium (Cd) & 1.00 \\
\hline Lead (Pb) & 0.05 \\
\hline Copper (Cu) & 30 \\
\hline Chromium (Cr) & 0.10 \\
\hline Tin (Sn) & 250 \\
\hline Mercury (Hg) & 0.01 \\
\hline Nickel (Ni) & 5.00 \\
\hline Selenium (Se) & 0.05 \\
\hline
\end{tabular}

To evaluate the tolerance values for cadmium, lead and copper, 15 samples of milk powder of various brands were acquired in the market in the city of Niterói (Rio de Janeiro, Brazil). All samples were calcined and digested in high purity nitric acid and bi distillate. After dissolution and dilution, the samples were taken read on an atomic absorption spectrophotometer with an electrothermal source, shown in Figure 10.

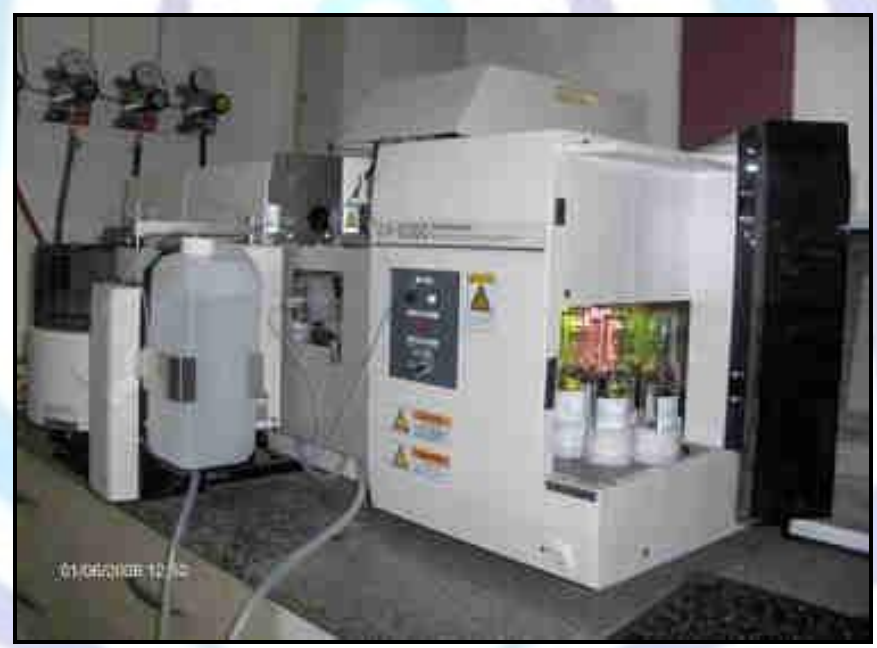

Fig. 10 - Atomic absorption spectrophotometry equipment with electrothermal atomization

The operational parameters used in the calibration of the equipment) Shimadzu AA-6300) are presented in Table 2.

Table 2- Operating parameters of atomic absorption spectrophotometer Shimadzu AA-6300 with a graphite furnace.

\begin{tabular}{|l|c|c|c|}
\hline \multirow{2}{*}{ Operating parameters } & \multicolumn{3}{|c|}{ Metallic elements } \\
\cline { 2 - 4 } & $\mathrm{Cd}$ & $\mathrm{Pb}$ & $\mathrm{Ni}$ \\
\hline Wavelength $(\mathrm{nm})$ & 228.8 & 283.3 & 232.0 \\
\hline Lamp current $(\mathrm{mA})$ & 8 & 10 & 0.2 \\
\hline Slit width $(\mathrm{nm})$ & 0.5 & 0.5 & Pyrolysis \\
\hline Graphite tube & High density & High density & 12 \\
\hline
\end{tabular}

The determination of nickel, lead and cadmium in milk samples must be undertaken judiciously. During the validation process of the method, identification was carried out and the necessary corrections were made on the basis of the losses by the volatilization of metals during the opening of the sample as well as some interference from array as these could 
affect the final analytical signal. Based on the standards for these metals, the detection and quantification limits were established, as determined by the conditions of analysis, and are given in Table 3.

Table 3 - Detection Limit (DL) and Quantification Limit (QL) for lead, cadmium and nickel

\begin{tabular}{|c|c|c|}
\hline Elements & $\mathbf{D L}(\boldsymbol{\mu g} / \mathbf{L})$ & $\mathbf{Q L}(\boldsymbol{\mu g} / \mathbf{L})$ \\
\hline $\mathrm{Pb}$ & 0.81 & 2.71 \\
\hline $\mathrm{Cd}$ & 0.02 & 0.07 \\
\hline $\mathrm{Ni}$ & 0.85 & 2.83 \\
\hline
\end{tabular}

\section{ASSESSMENT OF MILK POWDER SAMPLES}

In this evaluation, known lots of 15 milk powder samples of different brands were purchased in supermarkets in Niterói (Rio de Janeiro, Brazil). It is important to note that the milk brands were chosen randomly targeting the development of research of toxic metal contamination. It is important to clarify that this research had no legal or quality audit objectives regarding the brand of powdered milk.

The values found for lead, nickel and cadmium for all 15 milk samples analysed were below the limits of detection based on the methodology of graphite furnace atomic absorption. The values were: $\mathrm{Cd}<0.02 \mu \mathrm{g} / \mathrm{L}, \mathrm{Pb}<0.81 \mu \mathrm{g} / \mathrm{L}$ and $\mathrm{Ni}<0.85 \mu \mathrm{g} / \mathrm{L}$. These results may indicate that the production process of the milk powder placed on the market in this town was performed with very little contamination of these metals.

\section{CONCLUSIONS}

In the production process of milk powder, it is possible to accept two routes of contamination. The first refers to various kinds of contamination that can contaminate raw milk, such as organic, inorganic or biological substances. The second refers exclusively to mechanical wear (erosion) or corrosion of the equipment used in production. This means that industrial plants can theoretically be potential sources of the release of toxic metals through oxidation reactions that allow these metals to pass into the environment. Although most industrial plants use equipment made of stainless steel, which is more resistant to oxidative processes, some also use zinc or cadmium coated bolts, fittings, gaskets and insulation made of materials with toxic potential. Moreover, contamination can also occur during routine maintenance procedures for cleaning and disinfecting equipment and pipelines.

In this regard, developing analytical methodologies for the rapid identification of toxic metal contamination during the production process is critical to ensure the quality of the product and the health of the population. The method employed here using chemical analysis proved to be adequate to determine levels of metals such as nickel, lead and cadmium in powdered milk. It was comforting to find that the milk powder samples analysed for these metals contained levels at least ten-fold lower than the limits set by Brazilian legislation.

\section{REFERENCES}

[1] WHO. World Health Organization, 2004. Safety evaluation of certain food additives and contaminants. Sixty-first meeting of the Joint FAO/WHO Expert Committee on Food Additives (JECFA), p. 563.

[2] Santos, L. G. C. 2009. Confiabilidade metrológica da determinação de elementos tóxicos e essenciais em leite bovino de raças exploradas no Brasil. 2009. 124 p. Tese (Doutorado) - Centro de Energia Nuclear na Agricultura, Universidade de São Paulo, Piracicaba, Brazil.

[3] http://www.parana-online.com.br/, accessed in 30/12/2004.

[4] Correio da Manhã; Portugal, accessed in 18/12/2006.

[5] http://www.estadao.com.br/noticias/, accessed in 23/09/2010.

[6] Tamime, A. Y. 2009. Milk processing and quality management.Wiley.com, 2009.

[7] Chmielewski, R. A. N. \& Frank, J. F. 2003. Biofilm formation and control in food processing facilities. Comprehensive reviews in food science and food safety, 2(1), 22-32.

[8] Mittelman, M. W. 1998. Structure and functional characteristics of bacterial biofilms in fluid processing operations. Journal of Dairy Science, 81(10), 2760-2764.

[9] Barnes, L. M.; Lo, M. F.; Adams, M. R.; Chamberlain, A.H. L. 1999. Effect of Milk Proteins on Adhesion of Bacteria to Stainless Steel Surfaces. Applied and Environmental Microbiology. 65(10), 4543-4548.

[10] Bansal, B. \& Chen, X. D. A. 2006. Critical Review of Milk Fouling in Heat Exchangers, Institute of Food Technologists, Comprehensive Reviews in Food Science and Food Safety, 27(5).

[11] BansaL, B.; Chen, X. D.; Lin, S.X.Q. 2005. Skim milk fouling ohmic heating, ECI Symposium Series, Volume RP2, Proceedings of 6th International Conference on Heat Exchanger Fouling and Cleaning, Kloster Irsee, Germany, June 5-10. 
[12] Daufin, G.; Labbé, J. P.; Quemerais, A.; Brulé, G.; Michel, F.; Roignant, M.; Priol, M. 1987. Fouling of a heat exchange surface by whey, milk and model fluids. An analytical study, France, Le Lait, 67(3), p. 339-364.

[13] Pludek, V. R. 1977. Design and corrosion control, New York: John Wiley \& Sons.

[14] Roberge, P. R. 2000. Handbook of Corrosion Engineering, New York: The McGraw-Hill Companies.

[15] Moura, V.; Tavares, S. S. M.; Kina, A. Y.; Faria, M .M .S. G de; Mainier, F. B. 2009. Investigation of cracks and sensitization in an AISI 304L stainless steel exposed to 500-600 ${ }^{\circ} \mathrm{C}$. Engineering Failure Analysis, 16, 545551.

[16] Talbot, D. E., \& Talbot, J. D. 2010. Corrosion science and technology. CRC Press.

[17] Mainier, F. B., Monteiro, L. P. C., Fernandes, L. H., Oliveira, M. A. M., 2013. Restrictions on the use of cadmium coating in industries, Journal of Science and Technology, 3(2),176-180. 